\title{
Waste Material Recyclation in Abrasive Water Jet Technologies
}

\author{
Sobotová Lýdia, Badida Miroslav, Karková Monika
}

Technical university of Košice, Faculty of Mechanical Engineering, Department of Process and Environmental Engineering

\begin{abstract}
Recycling as a waste process technology is preferred in terms of environmental protection, today. Water jet technology is friendly and belongs to green technology. It is possible to divide as the paper material to the steel and can be divided into two principal groups described in the contribution. This progressive technology is applied in various sectors of industry. During the cutting operations creates the waste in the forms as polluted water, sludge, used abrasive material and other rest material from the semi- products. This contribution focuses on one type of waste - water. Water is an essential parameter in the process of water jet cutting machine and abrasive water jet machine. Water treatment takes place in filtration equipment, where the basic apparatus is filter. In the contribution is discussed several possibilities of recycling facilities, not only based on filtering. There were tested the water samples, taken from the process before and after the process. The composition of the water before cutting and after cutting operation were discussed and were compared the quality of water after recycling.
\end{abstract}

Keywords: Recycling, water jet technology, machine, filter, water

\section{Introduction}

The force of water in the form of erosion of materials is observed in nature for millions of years. High pressure water jet cutting has evolved continuously for decades in research and industry. An important design use water jet in production technology as a tool comes from the aircraft and aerospace industry.

Over the past five years, the number of cutting machines water jet sold worldwide, both abrasive and pure water has increased by an average of 18 percent per year. The issue of waste is still important. Economic production also needs to focus on reducing costs.

\section{Abrasive water jet technologies}

For cutting compact and hard materials, such as metals, glass, ceramics used abrasive cutting method. Before the beam touches the material added to the flow of water in the mixing chamber of the cutting tool - abrasive. [3]

The main part of the device is the cutting head, which produces high-speed water jet. Injection system supplies the abrasive particles into the high velocity jets. The water in the case, where the generator is supplied to the pressure, must meet all the requirements of the standards of the cutter head, Fig. 1. [2] Water in this technology enhances the quality of work, quality of products, equipment life, reduce repair, and reduces the wear rate of nozzles, control valves. The water used in the separation technology of water jet must be free from iron and calcium. The

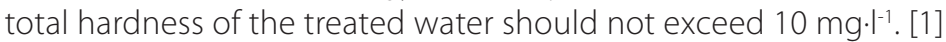


Soluble solids based on the solution and act as abrasive material. The most affected are the components of the nozzle and high pressure seals. [5]

When creating a high-speed abrasive jet, wear occurs mainly in focusing device due to shock tube solid phase on the inner wall of the tube. [2]

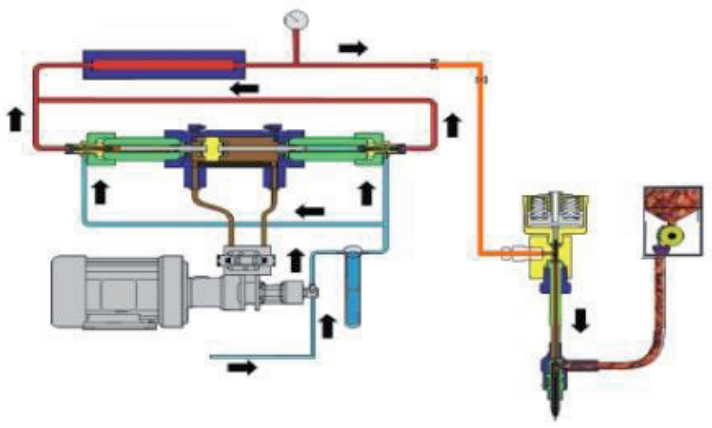

Fig. 1: The principle of water jet cutting - hydro abrasive erosion - AWJM[12].

\section{Quality of water}

Water in this technology enhances the quality of work, quality of products, equipment life, reduce repair, and reduces the wear rate of nozzles, control valves. The water used in the separation technology of water jet must be free from iron and calcium. The total hardness of the treated water should not exceed $10 \mathrm{mg} / \mathrm{l}$. The following Tab. 1 shows the allowed values of the substances contained in the cutting water in $\mathrm{mg}^{-1} \mathrm{I}^{-1}$ mentioned by the KMT firm, which has long been engaged in technology, cutting water jet. [1]

Components of systems for water jet cutting are subjected to high levels of stress, and are sensitive to the effect of the constituents in water. Therefore, there is local damage, therefore the corrosion. [1]

Soluble solids based on the solution and act as abrasive material. The most affected are the components of the nozzle and high pressure seals. [5]

\section{Quality of Abrasives}

Appropriate species of abrasive material to the cutting process depends on a number of factors. One of the most important factors is the availability and price. For abrasive quality is often pays a high price, but this speaks volumes about its quality and purity. It is important to avoid abrasive containing silica (causing silicosis) and thus increase the risk of

Table 1: Water quality.

\begin{tabular}{|l|l|l|l|}
\hline Water quality & Acceptable values & \multicolumn{1}{l|}{ Good values } & \multicolumn{1}{l|}{ Very good values } \\
\hline Parts life subject to wear & minimum & average & maximum \\
\hline Alkalinity $(\mathrm{mg} / \mathrm{l})$ & 50 & 25 & 10 \\
\hline Calcium $(\mathrm{mg} / \mathrm{l})$ & 25 & 5 & 0,5 \\
\hline Carbon dioxide $(\mathrm{mg} / \mathrm{l})$ & 0 & 0 & 0 \\
\hline Chloride as $\mathrm{Cl}(\mathrm{mg} / \mathrm{l})$ & 100 & 15 & 1 \\
\hline Free chloride $(\mathrm{mg} / \mathrm{l})$ & 1 & 1 & 0,05 \\
\hline Iron as Fe $(\mathrm{mg} / \mathrm{l})$ & 0,2 & 0,1 & 0,01 \\
\hline Manganese as $\mathrm{Mn}(\mathrm{mg} / \mathrm{l})$ & 0,1 & 0,1 & 0,1 \\
\hline Magnesium as $\mathrm{Mn}(\mathrm{mg} / \mathrm{l})$ & 0,5 & 0,1 & 0,1 \\
\hline Nitrates $(\mathrm{mg} / \mathrm{l})$ & 25 & 25 & 10 \\
\hline Oxygen $(\mathrm{mg} / \mathrm{l})$ & 2 & 1 & 0,1 \\
\hline pH $(1)$ & $6,5-8,5$ & $6,5-8,5$ & $6,5-8,5$ \\
\hline Silicon $($ silicate) $(\mathrm{mg} / \mathrm{l})$ & 15 & 10 & 1 \\
\hline Sodium $(\mathrm{mg} / \mathrm{l})$ & 50 & 10 & 1 \\
\hline Sulphates $(\mathrm{mg} / \mathrm{l})$ & 25 & 25 & 1 \\
\hline The total amount of dissolved solids $(\mathrm{mg} / \mathrm{l})$ & 200 & 100 & $5^{*}$ \\
\hline Total hardness as CaCO $(\mathrm{mg} / \mathrm{l})$ & 15 & 10 & 1 \\
\hline Turbidity $(\mathrm{NTU})$ & 5 & 5 & 1 \\
\hline
\end{tabular}


the operator. Its consumption ranges from 0.1 to $1 \mathrm{~kg} / \mathrm{min}$. The whole interface is associated with the type of pump and nozzle at WJ technology. $[10,11]$

Quality abrasives guarantee us increased cutting speed, higher accuracy, minimal clogging nozzles. Quality abrasive must be screened twice to have the sharpness (better cutting), and the purity of abrasives must be high. In addition to these abovementioned properties it is also good idea to check the thickness of the grain used by manufacturers of nozzles, to improve not only the process and the said cutting speed but increases the lifespan of the machine itself and the nozzle. $[10,11]$

\section{Experiment}

There exists various design of work, where you need to plan working space around the machine. To feed and to use of feed media in materials extraction also must count with the space, where is the stored waste from the production process.

Department DRC company based in Prešov, has coordinate table WJ-3020B $1 Z$ from PTV Prague and the high pressure pump 55 9XD from FLOW SYSTEMS. These facilities allow us to cut metal materials up to $200 \mathrm{~mm}$ thick.

Effective working area is $2000 \mathrm{~mm} \times 3000 \mathrm{~mm}$ with $200 \mathrm{~mm}$ stroke. Additional information about the performance of the work, customers are supplied either in the form of software (DWG, $D X G$ ), or in the form of drawings by subsequent workers converted to electronic form by entering the required performance of the product in the program that controls the cutting device.

In the company were made withdrawals of water samples before and after the cutting process the cutting process. These waters were analyzed, which serves as a means of demonstrating water quality and water quality changes for this to work.

The sample collected water through a threestage filtration using filter papers, Fig. 2.

The chemical composition of the collected samples was determined by optical emission spectrometry using optical emission spectrometry with inductively coupled plasma ICPE - 9000 by a Shimadzu (Fig. 3). Analysis was performed on the Department of Environment Process Engineering, Faculty of Mechanical Engineering, Technical University of Kosice

First is to be conducted by analysis of water,

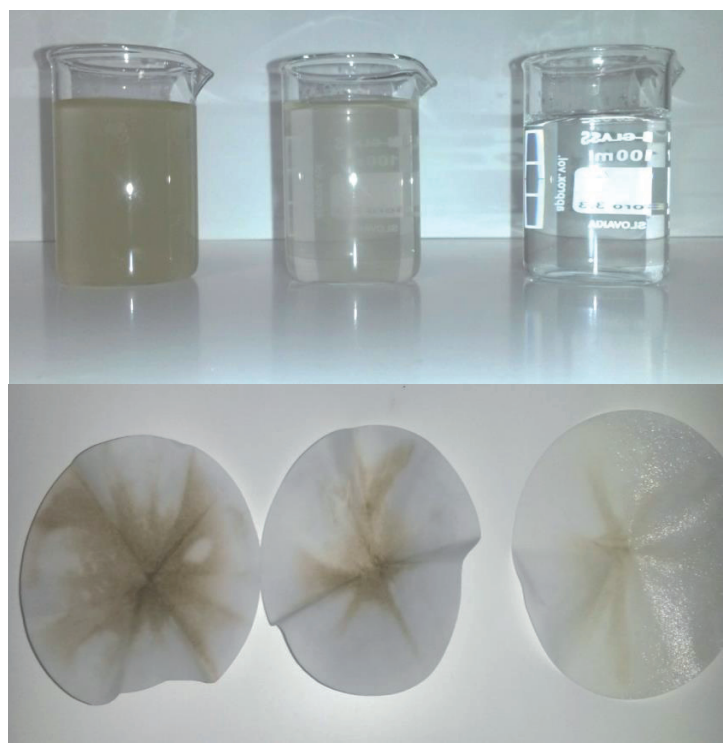

Fig. 2: Experimental samples.

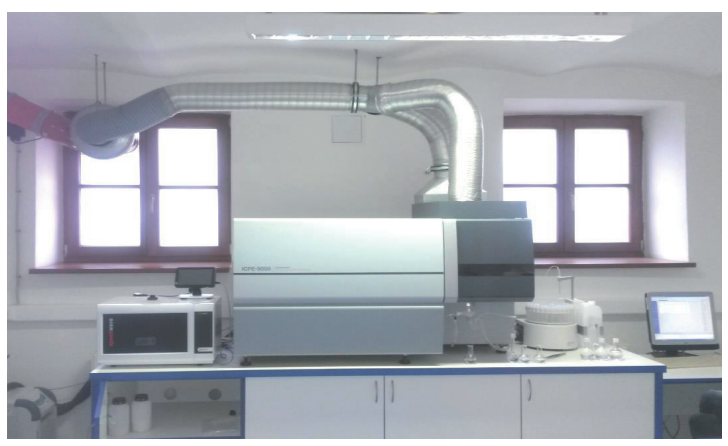

Fig. 3: Spectrometer ICPE 9000.

Table 2: Analysis of water before cutting process.

\begin{tabular}{|l|l|l|l|l|l|l|}
\hline $\mathbf{1 m g} / \mathrm{L}<=$ & Ca 96 & Mg 13 & Na 4.8 & Si 2.9 & & \\
\hline \multirow{4}{*}{ 1ug/L $<=$} & B 40 & Ba 23 & Be 2.7 & Fe 130 & Ir 900 & K 250 \\
\cline { 2 - 8 } & Li 1.6 & Mn 1.9 & Nb 26 & Pr 72 & Re 20 & Rh 140 \\
\cline { 2 - 8 } & Sr 110 & Zn 22 & & & & \\
\hline
\end{tabular}

which enters the cutting process, Table 2. Before entering the nozzle is used for cooling the pump and passes through the filter device.

Subsequently, the water is supplied by a pump line to a water tank, from where it is injected into the restricted area of the nozzle and produces a water jet. In the mixing chamber, the water mixed with abrasive. Thus prepared AWJ under the command and set parameters cut the selected material. Water is collected in traps water is polluted not only the abrasive particles but also cut material. Analysis 
of the water after the cutting process is shown in Table 3.

Table 3: Analysis of water after cutting process.

\begin{tabular}{|l|l|l|l|l|l|l|}
\hline $\mathbf{1 m g} / \mathbf{L}<=$ & Ca 96 & Mg 14 & Na 8.4 & Si 3.0 & & \\
\hline \multirow{4}{*}{$\mathbf{1 u g} / \mathbf{L}<=$} & B 110 & Ba 25 & Be 2.7 & Cu 35 & Fe 210 & Ir 920 \\
\hline & K290 & Li 1.6 & Mn 2.3 & Nb 26 & Pr 72 & Re 21 \\
\hline & Rh 140 & Sr 110 & Zn 23 & & & \\
\hline
\end{tabular}

By comparing of the measured results obtained by spectrometer, we can say that dirty water after small adjustments using a filtration device can be reused in the cutting process.

\section{Water recycling}

The water is filtered after working process for removal of abrasives. The filtration system for waste water is described in the literature [1] to use the force of gravity. It consists of a steel frame, and with the drive output shaft by means of which the transport chain is moving. It includes a filter Fleece liner. Chain is driven by an electric motor. Wastewater is on the belt, uniformly distributed, dirt collects fleece filter, which collects dirt and creates a trough. If a high level is automatically conveyed, new Fleece liner is added. [3]

Companies engaged in the cutting of materials using water jet technology, whether pure or abrasive, two ways to dispose of water are, Fig. 4, Fig. 5 and Fig. 6:

- recycling-therefore again to return to the workforce and using equipment and methods described in this chapter, where the company will save the environment and reduce water consumption by about half. Dirty water can be recycled already at 95$100 \%$ and to create a closed cycle.

- discharge - that water separated from the abrasive slurry to divert sewage, when a chemically unpolluted water. In the separation of heavy metals should be the vodka classified as hazardous waste and ensure business that such water subsequently treated.

Filters - are an integral part of the device. Remove dirt from the water the size of 0.5 to $1.2 \mathrm{\mu m}$. The filters are divided into two types:

\section{- low pressure,}

\section{- high pressure.}

Low pressure filters are used at the inlet of water to the multiplier. This is a conventional filters on the principle of synthetic fibers or cotton. In the multiplier increases the pressure of the water, which passes through the metal filter, which is in the form MIKROSA. [9]

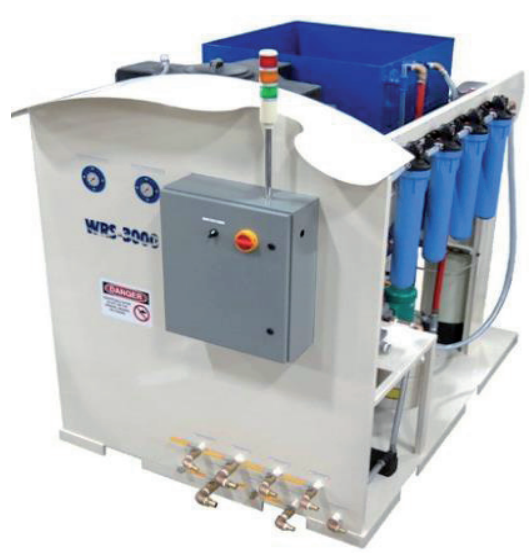

Fig. 4: WARD water treatment apparatus WRS 3000.

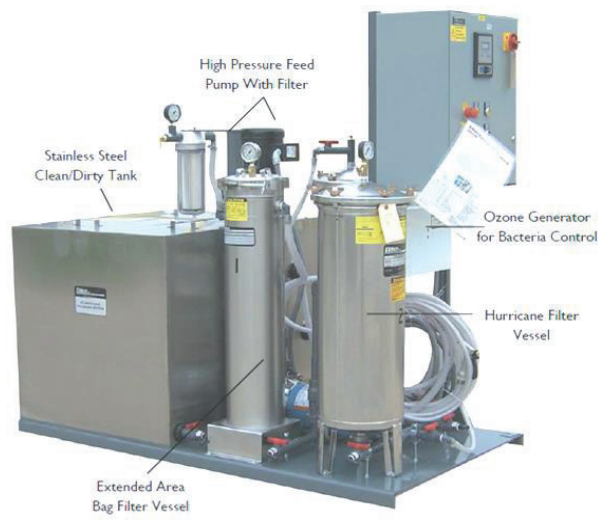

Fig. 5: The Closed Loop Filtration System Model \#CLS-161.

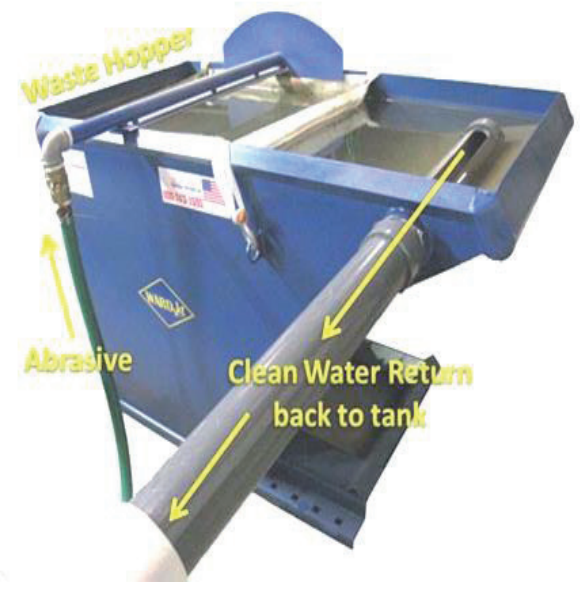

Fig. 6: Mini hopper. 


\section{Recycling of Abrasives}

Abrasive removal system is used for easy cleaning of the water collected in the tank, which works on the principle of the Venturi effect. Separate abrasive sand and sludge is deposited in a container outside the containment. [8]

For this experiment, draw conclusions, which show that the technology is safe and environmentally sound. The water can be recycled in the process with filter devices.

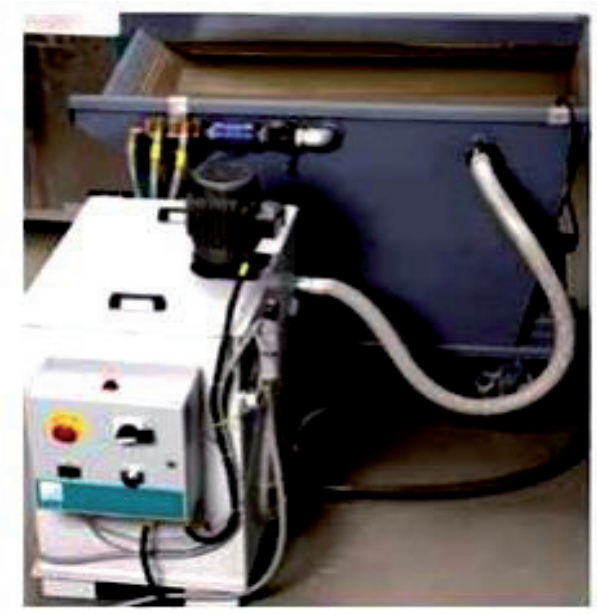

Fig. 7: Drain system [8].

Automated way - WARD- system is used for recycling using abrasives under running water, Fig. 7. It is a system to transfer and recycle the abrasive. [1] Its function is to:

- Removal of mud, debris from the tank, Fig. 8,

- Segregation of waste from abrasives,

- Wash and dry abrasives,

- in the final stage through a coarse screen [1].

The result of recycling are two products:

-Recycled abrasives - washed and dried it can be reused.

- Waste - sludge or mud. It is stored in 55-gallon barrels and 200 liter barrels. Sewage is easily compressible and is low in the water. [1]

\section{Conclusion}

To separate the materials at the start of the water and filtered using a pressure fed to the nozzle. Used water is purified by sedimentation tank from coarse dirt and then use the devices mentioned above or filters the water to prepare the required quality and returns to the process as cutting water.

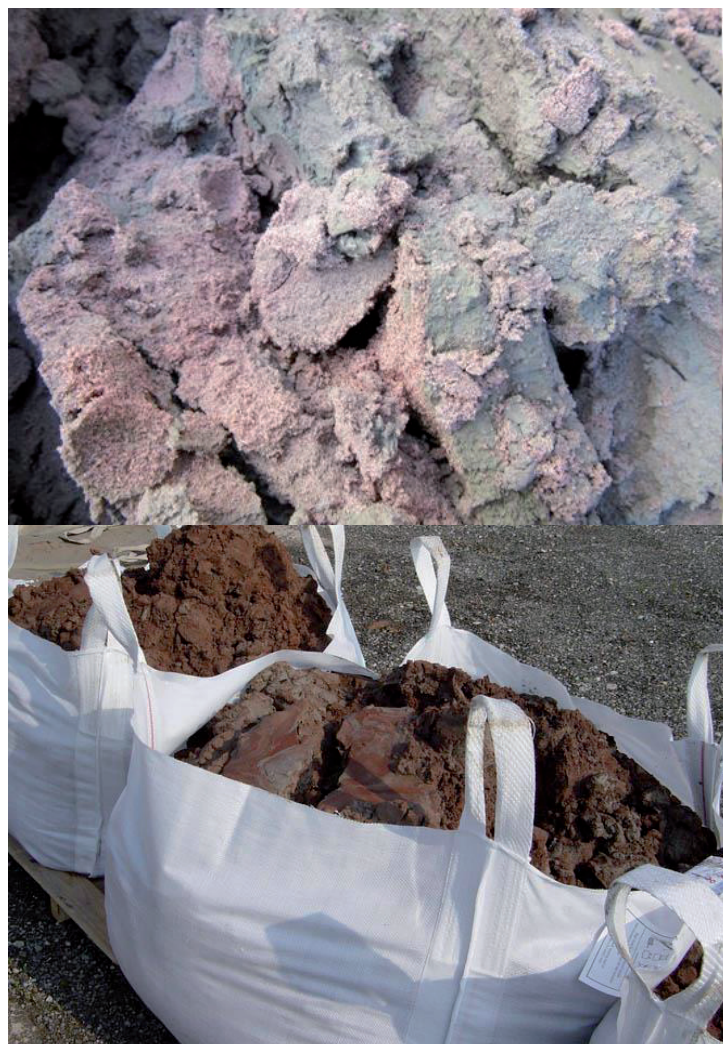

Fig. 8: Used abrasives.

\section{Acknowledgments \\ This article was part of the project KEGA 048TUKE-4/2015.}

\section{References and Notes}

[1] Kmec, J., Gombár, M., Bičejová, L., Dobrovič, J. (2011) Faktory hydroerózie. TU SjF Košice, p. 216

[2] Hires, O., Hatala, M., Hloch, S. (2007) Delenie kovových materiálov okružnou pílou, vodným prúdom a plazmovým oblúkom. Ostrava 2007, p.147

[3] Kmec, J., Kučerka, D., Gombár, M., Hrmo, R., Bičejová, L’. (2014) Delenie materiálu. TU SjF Košice, p. 287

[4] Salesmen presentation; KMT GmbH.KMT Waterjet System: KMT Creating value through precision,15slyde, Germany, p. 77

[5] Kmec, J., Bičejová, L., Nováková, M., Gombár, M. (2011) Rozdelený vodný lúč pre rezanie nerezových materiálov. TUKE, FVT Prešov, p. 143

[6] Kmec, J., Sobotová, L. (2010) Vodný lúč 25 rokov na Slovensku. Transfer inovácií, 18/2010, TU SjF Košice. pp.160164

[7] Krajný, Z. (2013) Konštrukcia zariadení na obrábanie vysokotlakovým vodným lúčom WJM. Strojírenství, Industry central EU. from http://www.industry-central.eu/cs/ clanky/ 
strojírenství/105-kontrukcia-zariadeni-na-obrabanievysokotlakovym-vodnym-lucom- wjm, accessed on 201302-16

[8] Kopečný, L. (2011) Abrazívni vodní paprsek. VUT Brno, from https://dspace.vutbr.cz/bitstream/handle/11012 /445/ DIPLOMOV_PRACE-ABRAZIVN \% C3 \%8D _VODNI _PAPRSEK -LIBOR_KOPECNY _2011.pdf?sequence $=1$, accessed on $2012-10-11$

[9] Tvaružek, M. (2012) Studie použití vodního paprsku. VUT Brno. from https://dspace.vutbr.cz /bitstream/handle /11012 /5059 /2012_ DP_ Tvaruzek_Martin_108046. pdf? sequence=2, accessed on $2012-10-11$

[10] Karková, M., Sobotová, L. (2013) Abrazívne materiály využívané pri delení materiálov AWJ technológiou. Transfer inovácií. Vol.13 no. 25 (2013), pp. 146-149

[11] Karková, M., Sobotová, L. (2013) Recyklácia abrazívnych materiálov pri technológii AWJ - 2013.Trendy a inovatívne prístupy $v$ podnikových procesoch.Conference Proceedings, TU Košice, pp. 1-7

[12] Spišák, E., Badida, M., Kmec " J., Sobotová, L. (2011) Identification of Structure of Hydro-Erosion Operation. Acta Mechanica Slovaca. Vol. 15, no. 2, pp. 80-86

[13] Salesmen presentation. WARD Pro abrasive recycling system (2015), from http://www.wardjet.com/recycling

\section{Biographical notes}

Dr.h.c. prof.Ing. Miroslav Badida, PhD., He is a graduate of Mechanical Faculty of Technical University of Kosice. His scientific and research work focuses on the field of environmental engineering. An accent is put on the issue of clean manufacturing, clean technologies, recycling technologies, ecologization of products and their production and life cycle analysis of products. Lately his attention is paid on the research in the field of physical factors of working and living environment.

doc. Ing. Lýdia Sobotová, PhD., She is a graduate of Mechanical Faculty of Technical University of Kosice. Her scientific and research work focuses on the field of mechanical technology and materials and environmental engineering. An accent is put on the issue of clean technologies, recycling technologies, recycling of materials, utilization of production waste. Lately her attention is paid on the research in the field of joining of materials, ageing of materials and material processing.

Ing. Monika Karková, PhD., (1986) graduated on the Technical University of Kosice, Faculty of Mechanical Engineering, in the field of Environmental Engineering, in 2010 she defended her diploma thesis on "Project closure and biological restoration of TPZ pond in SE - EVO". She is currently PhD student at KPaEl, FME, TU in Košice. She attended several study stays abroad in KSA, TUL, during her PhD study. In the academic year 2014/2015 she studied at FST UWB KPIaM via ERASMUS+ study program. Within the dissertation thesis of doctoral studies she is focusing on the topic of "Waste reduction potential in the application of water jet technology." The results of it her research activities have been published in many domestic and foreign magazines, as well as domestic and foreign conferences. 